\title{
A Comparative Study of Human Resource Management Practices and Its Impact on Organizational Performance in Indian Public Sector Banks
}

\author{
Dr. Rafia Gulzar \\ Assistant Professor \\ Dar Al Uloom University \\ Riyadh KSA, Saudi Arabia \\ E-mail: rafia@dau.edu.sa
}

Received: Oct, 25, 2017 Accepted: Nov. 13, 2017 Online published: Nov. 20, 2017

doi:10.5296/ijhrs.v8i1.12048ＵRL: https://doi.org/10.5296/ijhrs.v8i1.12048

\begin{abstract}
The main purpose of this study was designed to explore and compare Human Resource Management practices and their impact on organizational performance in Indian Public Sector Banks. Human Resource Management is very important for banks because banking is a service industry. Research suggests that service quality has been increasingly recognized as a crucial factor that determines the level of success of any business Human input is the single largest input to the banking industry. The level of efficiency/productivity of this input is reflected in the quality of service offered by the banks to its customers, as also in its ultimate growth, productivity and profitability. Human Resource Management Practices has been studied extensively in Multinational companies, education sector and manufacturing sector. However only a few research has been conducted in banking industry. Even these researchers have not compared Human Resource Management Practices Public Sector banks in Jammu and Kashmir. The research was based on self-administered questionnaire survey of total 266 employees. It consists of 11 managers and 33 subordinates from PNB and 18 managers and 54 subordinates from SBI. The main HRM practices studied were General climate, OCTAPACE culture, Selection, job definition, career planning, training, performance appraisal and compensation. The data were analyzed statistically and finding revealed that HRM practices have huge impact on the organizational performance in banking sector. At the end research also depicted some limitation as well as future research directions.
\end{abstract}

Keywords: human resource management practices, public sector banks, PNB, SBI 


\section{Introduction}

Since 1960s, the Indian banking industry became an important tool to facilitate development of the Indian economy. Banking sector has emerged as a large employer, and numerous debates have ensued about the possibility to nationalize banking sector. Mrs. Indira Gandhi, the then Prime Minister of India expressed that the intention of Government of India (GOI) was to nationalize the banking sector. It was mentioned in the paper entitled "Stray thoughts on Bank Nationalization." presented in the annual conference of the All India Congress Meeting. The paper was received with a high degree of positive enthusiasm. Thereafter, her move was swift and sudden, and the GOI issued an ordinance and nationalized fourteen (14) largest commercial banks with effect from the midnight of July 19, 1969. Jayaprakash Narayan, a national leader extremely high stature, described the step as a "masterstroke of political sagacity." Within two (2) weeks of issuing the ordinance, the Parliament passed Banking Companies (Acquisition and Transfer of Undertaking) Bill, and it received the presidential approval on 9th August, 1969.

A second $\left(2^{\text {nd }}\right)$ installment of nationalization of six (6) additional commercial banks followed in 1980. The reason stated for the nationalization "to give the government more control of credit delivery". With the second $\left(2^{\text {nd }}\right)$ dose of nationalization, Government of India controlled around 91\% of the banking business of India. Later on in 1993, New Bank of India (one of the Nationalized Banks) was merged with Punjab National Bank (PNB). It was the first and only merger of one Nationalized Bank into another Nationalized Bank, reducing the number of Nationalized Banks from twenty (20) to nineteen (19). After this merger, until the 1990 s, the nationalized banks grew at a pace of around four percent (4\%), closer to the average growth rate of the Indian economy.

Currently banking sector in India is fairly mature in terms of supply, product range and reach in urban centres. Rural India still remains a challenge for the private sector and foreign banks. In terms of quality of assets \& capital adequacy, Indian banks are considered to have clean, strong and transparent balance sheets relative to other banks in comparable economies in the region. The Reserve Bank of India being an autonomous body, with minimal pressure from the government is able to function independently. The stated policy of the Bank as mentioned on the Indian Rupee is to manage volatility, without any fixed exchange rate $\&$ this has mostly been true.

Current indicators show that growth in Indian economy is expected to be strong for quite some time especially in its services sector, therefore the demand for banking services, especially retail banking, mortgages and investment services are expected to be vibrant \& strong. One may also expect mergers and acquisitions (M\&As), takeovers, and as set sales.

\section{HRM Practices in Banking Industry}

The HRM practices in banks are steadily forging ahead. Majority of the banks have set up separate HRD Departments (HRDDs) within a decade of their coming into operations; HRDDS in some banks have gained certain valuable achievements. Certain people have extended blanket criticism of the existing HRM functions as "Ornamental Appendages" 
cannot be justified. However, it is a fact that functioning in a majority of the banks is far from satisfactory. Instances have been reported from within banks where HRDD discharged personnel administrative functions of recruitment, placement, transfer, promotion and training. The functioning of the HRDD in many banks shows a transition towards HRD functions. In these banks, in addition to training, certain other activities like manpower planning and performance appraisal have been introduced. Yet, a few other banks have made rapid strides as far as the introduction of new HRM activities and sub-systems are concerned, e.g. quality circles, staff meetings \& systematic induction are concerned besides introducing these systems, some banks have also taken appreciable efforts in perfecting functions like training and performance appraisal. Nevertheless, there is a widespread feeling in the banking sector that there are no sufficient pay offs from the HRM functions and the system at the operational level are relegated to mere rituals. The linkages between HRD systems and other related such systems in HRM are also not very obvious.

There is a need to make Indian Banking System stronger, efficient \& low-cost. This can be achieved by creation of fundamentals that must be included in the banks strategies, operations $\&$ processes; strengthening the prudential norms \& market discipline; adoption of international/global benchmarks to optimize operations; change management \& consolidation within existing financial system; upgrading technological infrastructure of the financial system; \& development of human resources as a catalyst for transformation. Human Resource Management within the Banking sector is considered as one of the "pillars" of process of discovery \& transformation. The field of Human Resource Management can be described as vibrant, dynamic and emergent within the cultural aspect in the Banking sector. The success of today's banking business will depend on how effectively and efficiently the human resources of the organization are utilized. The evolution of the whole banking system in India has affected the human resource practices, recruitment and selection conventions \& practices, and training system. It is important that the details of human resource philosophy within a bank are discussed along with the employees, to build \& plan their own career-path, planning, perceptions and development. It goes without saying that the primary strength of the industry is the human capital that is why the efforts to develop the skills is important.

\section{Research Objectives}

- To compare HRM practices and how well HRM tasks are performed in public sector banks.

- To study about the effectiveness of HRM practices on organizational performance in public sector banks.

- Based on the findings, to offer suggestions for improvements in the HRM system in public sector banks.

\section{Need for the Present Study}

Various past research studies indicate that some of the organization and their managements show great interests and faith in implementing HR practices and mechanisms in order to improve the level of satisfaction among their employers and employees and in return improves the overall performance of the organization. The existence of efficient, trained and 


\section{Macrothink}

International Journal of Human Resource Studies

ISSN 2162-3058 2018, Vol. 8, No. 1

developed workers are key to survival of an organization and especially of the service oriented industry like commercial banks, where improvements in service have to be made to meet the rising expectations of the customers. How efficiently and effectively have commercial banks being able to meet the rising expectations of its customers would naturally depend upon how best the management and these institution have taken care for the development of its employees. The supremacy of human resource and the urgency of its development, make out a strong care for the evaluation of the development of HR practices in the banking sectors.

Keeping this in view, an attempt has been to study the existing Impact of HR practices on Organizational performance in banks with special reference to national banks.

\section{Hypothesis}

H1: There is close relationship between HRM practices and organizational performance.

H2: HRM practices has positive impact on organizational performance in banking sector.

\section{Structure of the Indian Banking}

Banks in India can be classified into two categories, commercial banks and cooperative credit institutions. Within the category of commercial banks, there are two types of Banks, namely scheduled commercial banks and non scheduled commercial banks. Depending upon the pattern of ownership, commercial banks can be classified into two groups. These are

1. Public sector banks which includes SBI (State Bank of India) \& its associates, regional rural banks \& nationalized banks.

2. Private sector banks, consisting of Indian private sector banks (which can be sub divided into two i.e. banks existing prior to 1991 and banks established after 1991) and foreign banks operating in India.

3. Others comprising of Regional rural banks and local are banks. 
Exhibit 1.1. Structure of Indian Banking

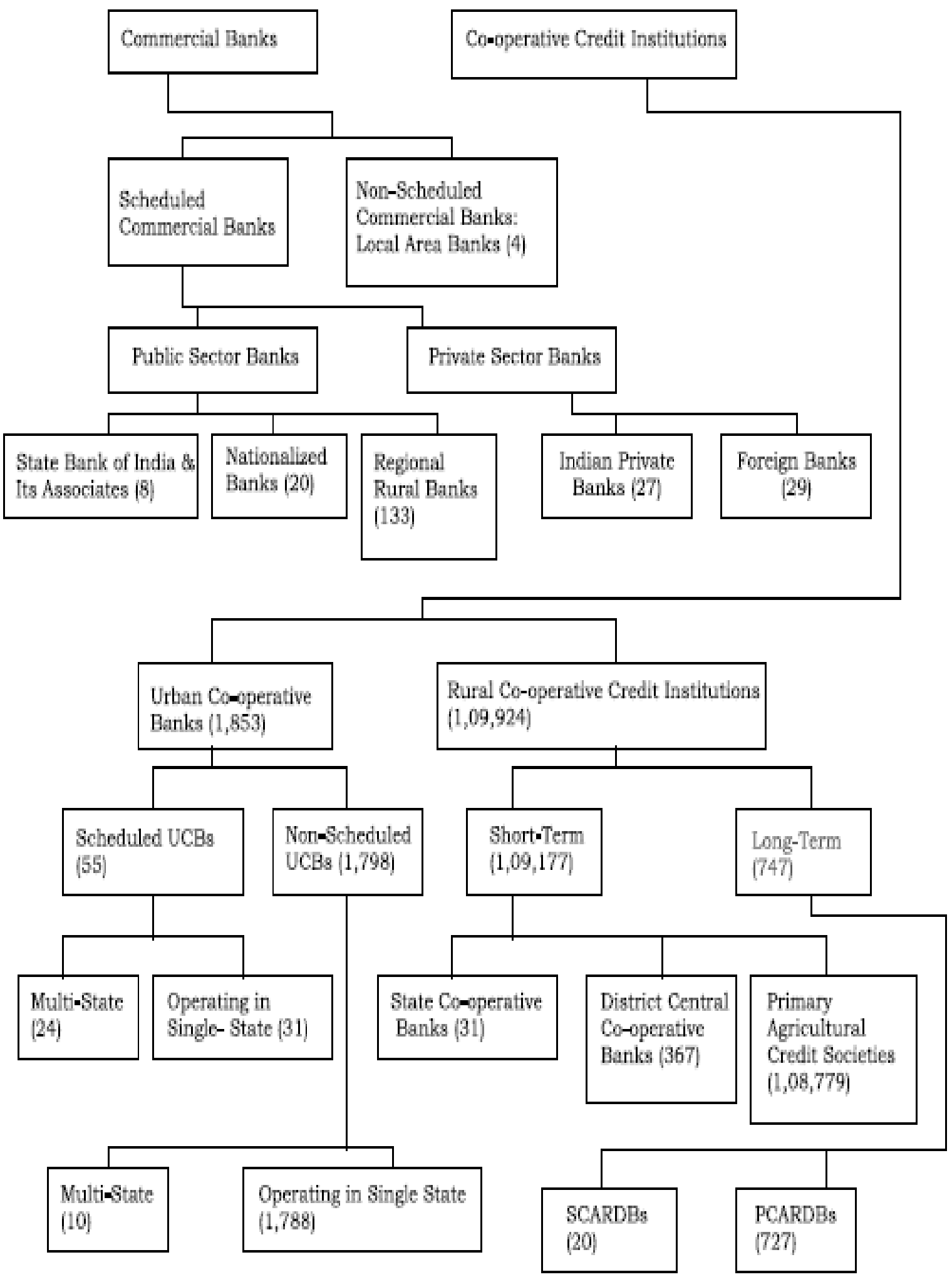




\section{MInstitute ${ }_{\text {Intm }}^{\text {Macrothink }}$}

International Journal of Human Resource Studies

ISSN 2162-3058 2018, Vol. 8, No. 1

After the brief overview of the history and structure of banking in india, a brief introduction of the banking organization under study needs to be discussed here.

\subsection{State Bank of India (SBI) Ltd}

The establishement of SBI (State Bank of India) dates back to the first decade of the nineteenth $\left(19^{\text {th }}\right)$ century with establishment of the Bank of Calcutta on 2 June 1806. Three (3) years later the bank received its charter and was re-designed as Bank of Bengal on 2 January 1809. As a unique institution, SBI was first joint-stock bank of British India sponsored by Government of Bengal. Bank of Bombay (15 April 1840) \& Bank of Madras (1 July 1843) followed the Bank of Bengal. These three banks remained at the pinnacle of modern banking in India till their merger as the Imperial Bank of India on 27 January 1921.

SBI (State Bank of India), the largest bank in the country has a network of over 13,542 branches \& 5 associate banks in India \& 131 foreign offices in 32 countries. SBI offers its customers the convenience of over 21000 ATMs in India, already the largest network in the country. At the time of inception of the State Bank of India, it had only 466 branches. In 1959 State Bank of India (subsidiaries Banks) Act was passed under which eight subsidiary state banks were also taken over and reconstructed into seven (7) subsidiaries of the State Bank of India. These are i) State Bank of Jaipur, ii) State Bank of Hyderabad, iii) State Bank of Indore, iv) State Bank of Mysore, v) State Bank of Patiala, vi) State Bank of Saurashtra, vii) State Bank of Tranvencore.

Exhibit 1.2. A brief review of SBI Performance (2011-15)

\begin{tabular}{l|l}
\hline No. of Branches & 13,542 \\
\hline Revenue (US\$) & $\$ 36.950$ billion. \\
\hline Profit & $\$ 3.202$ billion. \\
\hline Total assets & $\$ 359.237$ billion \\
\hline Total equity & $\$ 20.854$ billion \\
\hline No. of people employed & 292,215 \\
\hline Employee cost & $6 \%$ of sales \\
\hline Owner(s) & Government of India \\
\hline
\end{tabular}

Sources: (BT-KPMG May 2015)

\subsection{Punjab National Bank Ltd}

'PNB was established on May 19, 1894. The founding board was drawn from diverse parts of India constituting of different faiths and a varied background. However, the common objective was to provide people of India with a truly national bank which would keep economic interest of the country as a top-most priority.

During FY'14, Punjab National Bank (PNB) maintained its \#1 position in domestic deposits, domestic business, domestic advances, operating profit \& CASA deposits amongst nationalized banks. The highlights of the PNB's performance in terms of business and profit are shown as follows: 
Exhibit 1.3. Highlights of the PNB's performance

\begin{tabular}{cccccccc}
\hline Parameters & Mar'09 & Mar'10 & Mar'11 & Mar'12 & Mar'13 & Mar'14 & $\begin{array}{c}\text { CAGR } \\
(\boldsymbol{\%})\end{array}$ \\
\hline Operating Profit & 5690 & 7326 & 9056 & 10614 & 10907 & 11384 & $14.88 \%$ \\
Net Profit & 3091 & 3905 & 4433 & 4884 & 4748 & 3343 & $1.58 \%$ \\
Deposit & 209760 & 249330 & 312899 & 379588 & 391560 & 451397 & $16.56 \%$ \\
Advance & 154703 & 186601 & 242107 & 293775 & 308796 & 349269 & $17.69 \%$ \\
Total Business & 364463 & 435931 & 555005 & 673366 & 700356 & 800666 & $17.05 \%$ \\
\hline
\end{tabular}

With $38.30 \%$ share of CASA Deposits to Total Deposits, PNB maintained its \#1 position amongst peers. In terms of bottom line performance, PNB achieved highest Operating Profit of Rs 11,384 crore during FY'14. Net Interest Margin (NIM) at 3.44\% remained one of the highest amongst peer banks.

PNB has a strong capital base with capital adequacy ratio of $12.29 \% \& 11.52 \%$ as per Basel III as on Mar'14. PNB maintained its \#1 position with highest book value per share of Rs.952.50 as at the end Mar'14 amongst peer banks.

\section{Review of Literature}

Banking is delivering variety of services to its ultimate customer right across the counter in the service sector. The activities of banking industry are all about "relationship". Hence, banking industry has to provide better services to their customers with a smile to built and sustain long term bank-customer relationship. Even with highland of technology banking sector is primitive and is dependent on human face of human resource management. The technology is merely an aid to the human face but cannot be substituted by any machine.

Recognition to HR as an important component in the development and learning processes in banking sector is the key to success and reward as human resource is supreme than all other resource in any organization. According to Vandana and punia (2004), "the managerial functions can be performed by human beings only and not by machines". Human resource has substantially enhanced its value as the "Core Resource" especially when there is cut throat competition between organizations in a competitive market. According to Rao (1992), human resource is a crucial to the organizational as a heart is to the body'. Human resource is probably the only resource which is capable of providing sustained competitive advantage to organization in globalized world. In the content of this significance human resource as the core resource has earned a position of dignity. According to Schuler (1994), in a worldwide IBM study, $67 \%$ of the CEOs and $72 \%$ of the executives believed that the HR is critical to the success of business today. Similar concern regarding the HR role and effectiveness in the new business context has been articulated across the world (Shandur \& Teo, 1999; Schular, Dowling and Decieri, 1993; Scarpello, 1994; Ulrich, 1998; Wright and McMahan, 2001; Bowen, Galang \& Pillai, 2002; Mitsuhashi, Park, Wright \& Chua, 2000; Tung-Chun Huang, 2002; and Agarwala, 2002. Empirical studies have also found that efficient use of HR has been instrumental in forging larger gains. A study by Singh (2000) of 84 Indian organizations found significant relationship between investment in the HR and the firm performance. It was in line with the past research findings. Some of the studies conducted in the recent past have shown encouraging results. (Kleiner, 1990; Boudreau, 1991; Johnes 
and Wright, 1992; Dyer and Reeves, 1995; Becker and Gerhart, 1996; Guest, 1997; Delery and Doty, 1996. In their study of the HR practices, Huselid and Becker (1997) and Bilmes et al. (1997), found that differences in HR practices are associated with large differences in financial performance. Beckar and Gerhart (1996) resolved that reasonable changes in an HR system can affect a firm's market value by $\$ 15000-45000$ per employee and can affect the probability of survival in respect of a new firm by as much as $22 \%$. Similar findings were observed by Welbourne and Andrews (1996). Sharif, Dowling and Liesch (1998), found that the HR management plays a significant role in international joint venture success. Similar results were found by Huselid, 1995; MacDuffie, 1995 and Huselid and Becker, 1995. According to Bandarker (2003), "some of the global giants (ABB, GE, IBM and Motorola) who underwent transformation, made specific efforts at people mobilization, especially through effective human resource management". Human resources in terms of reported research findings yield substantial results even in complex situations achieving organizational productivity and excellence. According to Miejia, Balkin, \& Cardy (2003), HR mean the "people who work in an organization". However, Megginson (1972) defines the term human resources as "the total knowledge, skills, creative abilities, talents and aptitudes of an organization's workforce as well as the value, attitudes and beliefs of the individuals involved." According to Pal (1997) ,"it includes the various facets of human energy and Capability such as - knowledge, skills, attitude, behavior, experience, motivation, physical and mental strength, capacity for growth, etc. The people working in an organization at all levels are owners and users of these resources".

Keeping in view the paramount significance of HRD and its contribution on overall performance of an organization, an effort has been made to have an overview of research studies in the area of HRM mechanisms in the banking industry. It may be mentioned here that very limited research has been conducted on HRM practices in banking sector. The following review of literature will unfold a broader canvas of empirical and conceptual studies that would determine the paramount importance of HRM practices in the banks and its positive impact on individual behavior, performance and organizational effectiveness. A brief schematic view of definitions of variables used from literature perspective is given in Exhibit 1.4.

Exhibit 1.4. Schematic view of definitions of variables used from literature perspective

\begin{tabular}{|c|c|c|c|c|}
\hline $\begin{array}{c}\text { S. } \\
\text { No. }\end{array}$ & $\begin{array}{c}\text { Year of } \\
\text { publicat } \\
\text { ion }\end{array}$ & $\begin{array}{c}\text { Author's } \\
\text { Name }\end{array}$ & Source & Definitions/conceptual framework \\
\hline \multicolumn{5}{|c|}{ Human Resource Management } \\
\hline .1 & 2009 & Pynes, J. E. & $\begin{array}{l}\text { Human resources management for } \\
\text { public and nonprofit organizations: } \\
\text { A strategic approach. USA: A } \\
\text { Wiley Imprint. }\end{array}$ & $\begin{array}{l}\text { HRM is the formal system that includes } \\
\text { philosophy, policies, and practices in an } \\
\text { organisation to ensure that it effectively } \\
\text { utilizes the knowledge, skill, abilities, and } \\
\text { other characteristics of the employees to } \\
\text { achieve the organisational goals }\end{array}$ \\
\hline 2 & 2011 & $\begin{array}{l}\text { Foss, N. J., } \\
\text { Laursen, K., } \\
\text { and Pedersen, } \\
\text { T. }\end{array}$ & $\begin{array}{c}\text { Linking Customer Interaction and } \\
\text { Innovation: The Mediating Role of } \\
\text { New Organizational Practices. } \\
\text { Organization Science, 22(4): } \\
\text { 980-999. }\end{array}$ & $\begin{array}{l}\text { HRM practices are considered in the literature } \\
\text { involve a) delegation of responsibility b) } \\
\text { incentives of knowledge e.g. profit sharing c) } \\
\text { internal communication d) training of } \\
\text { employee (internal and external training) and } \\
\text { e) hiring, recruitment \& retention. }\end{array}$ \\
\hline
\end{tabular}




\begin{tabular}{|c|c|c|c|c|}
\hline \multicolumn{5}{|c|}{ Organization Performance } \\
\hline 3 & 1995 & $\begin{array}{l}\text { Dyer, L., \& } \\
\text { Reeves, T. }\end{array}$ & \begin{tabular}{|} 
'Human resource strategies and \\
firm performance: What do we \\
know and where do we need to \\
go?', International Journal of \\
Human Resource Management, 6, \\
$656-670$ \\
\end{tabular} & $\begin{array}{l}\text { Organizational performance is generally } \\
\text { indicated by effectiveness (whether an } \\
\text { organization can achieve its objectives), } \\
\text { efficiency (whether an organization uses } \\
\text { resource properly). }\end{array}$ \\
\hline 6 & 2007 & $\begin{array}{l}\text { Katou, A. A., } \\
\text { and Budwar, P. } \\
\text { S. }\end{array}$ & $\begin{array}{l}\text { The Effects of Human Resource } \\
\text { Management Policies On } \\
\text { Organizational Performance In } \\
\text { Greek Manufacturing Firms. } \\
\text { Thunderbird International } \\
\text { Business Review, Vol.49, No.1, } \\
\text { pp.1-35. }\end{array}$ & $\begin{array}{l}\text { Performance is a satisfaction of employees } \\
\text { and customers, innovation quality of products } \\
\text { and services and ability to maintain a unique } \\
\text { human pool. }\end{array}$ \\
\hline \multicolumn{5}{|c|}{ Job Definition } \\
\hline 7 & 2006 & $\begin{array}{l}\text { Qureshi. M. } \\
\text { Tahir, }\end{array}$ & $\begin{array}{c}\text { Impact of Human Resource } \\
\text { Management Practices on } \\
\text { Organizational Performance in } \\
\text { Pakistan, Muhammad Ali Jinnah } \\
\text { University, Islamabad. } \\
\end{array}$ & $\begin{array}{c}\text { It clearly outlines responsibilities, duties, } \\
\text { working condition and expected skills of an } \\
\text { individual/worker performing that particular } \\
\text { job. }\end{array}$ \\
\hline 8 & 2010 & Pavur, E. R. & $\begin{array}{l}\text { Use job descriptions to support } \\
\text { leadership. The } \\
\text { Psychologist-Manager Journal, } \\
\text { 13(2), 119-122. }\end{array}$ & $\begin{array}{l}\text { Job descriptions which are used for } \\
\text { recruitment are intended to gain the attention } \\
\text { of and attract applicants }\end{array}$ \\
\hline \multicolumn{5}{|c|}{ Career planning } \\
\hline 9 & 1993 & Michael & $\begin{array}{l}\text { Perspective Management, } \\
\text { Himalaya Publishing House } \\
\text { Bombay, } 682 .\end{array}$ & $\begin{array}{l}\text { Career planning stands for the forward } \\
\text { looking employment policies of an } \\
\text { organization which takes into account the } \\
\text { career of individual executives involved in } \\
\text { various tasks, particularly critical tasks. }\end{array}$ \\
\hline 10 & 1999 & Rao, T V & $\begin{array}{l}\text { HRD Audit, New Delhi: Response } \\
\text { Books (A Division of Sage } \\
\text { Publications) New Delhi. }\end{array}$ & $\begin{array}{l}\text { Career opportunities and rewards are } \\
\text { important factors in providing a } \\
\text { developmental climate in any organization. }\end{array}$ \\
\hline 11 & 2003 & Manolescu, A. & \begin{tabular}{|c|} 
Human Resource Management, \\
4th Edition, The Economic \\
Publishing House, Bucarest, p.332
\end{tabular} & $\begin{array}{c}\text { Career planning is a continuous process for an } \\
\text { individual to develop his own occupational } \\
\text { concept as a result of skills or abilities, needs, } \\
\text { motivations and aspiration. }\end{array}$ \\
\hline \multicolumn{5}{|c|}{ Employees Participation } \\
\hline 13 & 1997 & $\begin{array}{l}\text { Locke, E.A., } \\
\text { and } \\
\text { Schweiger, } \\
\text { D.M. }\end{array}$ & $\begin{array}{c}\text { Participation in Decision-making: } \\
\text { One More Look. Research in } \\
\text { Organizational Behaviour, 1: } \\
265-339 .\end{array}$ & $\begin{array}{l}\text { Employee participation in decision-making } \\
\text { can be classified in terms of three properties. } \\
\text { These are formal-informal, direct-indirect, } \\
\text { and amount of influence. Formal } \\
\text { participation has a system of rules to be } \\
\text { followed, while informal participation can be } \\
\text { casual like a conversation with a supervisor. } \\
\text { Direct participation involves immediate } \\
\text { personal involvement, while indirect } \\
\text { participation involves some sort of employee } \\
\text { representation. }\end{array}$ \\
\hline 14 & 1998 & \begin{tabular}{|l|} 
Heller, F., \\
Pusic, E., \\
Strauss, G. and \\
Wilpert, B. \\
\end{tabular} & $\begin{array}{c}\text { Organisational Participation: Myth } \\
\text { and Reality, Oxford: Oxford } \\
\text { University Press. }\end{array}$ & $\begin{array}{c}\text { Participation has been defined as a process } \\
\text { which allows employees to exert some } \\
\text { influence over their work and the conditions } \\
\text { under which they work. }\end{array}$ \\
\hline 15 & 2004 & $\begin{array}{c}\text { Newstrom and } \\
\text { Davis }\end{array}$ & $\begin{array}{c}\text { Employee Participation in } \\
\text { Decision Making in RMG sector } \\
\text { of Bangladesh: Correlation with } \\
\text { Motivation and Performance. } \\
\text { Journal of Business and } \\
\text { Technology (Dhaka) 5(2), 122-132 }\end{array}$ & $\begin{array}{l}\text { Participation as a mental and emotional } \\
\text { involvement of people in group situations that } \\
\text { encourages them to contribute to group goals } \\
\text { and share responsibility for them. }\end{array}$ \\
\hline
\end{tabular}




\begin{tabular}{|c|c|c|c|c|}
\hline \multicolumn{5}{|c|}{ Performance Appraisal } \\
\hline 16 & 2006 & Jawahar, I. M. & $\begin{array}{c}\text { Correlates of satisfaction with } \\
\text { performance appraisal feedback. } \\
\text { Journal of Labor Research, 27(2), } \\
\text { 213-236. }\end{array}$ & $\begin{array}{l}\text { To provide feedback to the employees based } \\
\text { on their performance which is important to } \\
\text { both the employees and the organization. }\end{array}$ \\
\hline 17 & 2008 & $\begin{array}{l}\text { Hussain-Ali, } \\
\text { M.A.M. and } \\
\text { H.H.D.N.P. } \\
\text { Opatha, }\end{array}$ & $\begin{array}{l}\text { Performance appraisal and } \\
\text { business performance: An } \\
\text { empirical study in Sri Lankan } \\
\text { apparel industry. Sri Lankan J. } \\
\text { Hum. Resour. Manage., 2(1): } \\
\text { 74-90. }\end{array}$ & $\begin{array}{l}\text { Performance appraisal is perceived degree to } \\
\text { which performance appraisal system has } \\
\text { attributes those are right for fair and accurate } \\
\text { evaluation of employee job performance. }\end{array}$ \\
\hline 18 & 2009 & Andrews, S. & $\begin{array}{c}\text { Human resource management: A } \\
\text { textbook for the hospitality } \\
\text { industry. New Delhi: McGraw-Hill } \\
\text { Publishing Company Ltd }\end{array}$ & $\begin{array}{l}\text { The performance appraisal is a formal, } \\
\text { structured system that evaluates job related } \\
\text { behaviours of employees and their } \\
\text { contributions to the organisation that is } \\
\text { designed to manage the organisation's human } \\
\text { resources. }\end{array}$ \\
\hline 20 & 2011 & Sudin, S. & $\begin{array}{c}\text { Fairness of and satisfaction with } \\
\text { performance appraisal process. } \\
\text { 2nd International Conference on } \\
\text { Business and Economic Research. }\end{array}$ & $\begin{array}{c}\text { The performance appraisal is a managerial } \\
\text { process that relates the organisational } \\
\text { objectives, performance standard, and } \\
\text { evaluation to the performance review that is } \\
\text { applied. }\end{array}$ \\
\hline \multicolumn{5}{|c|}{ Training and Development } \\
\hline 21 & 2001 & Armstrong, M. & $\begin{array}{c}\text { A Handbook of Human Resource } \\
\text { Management Practice, Kogan } \\
\text { Page, 8th Ed. }\end{array}$ & $\begin{array}{c}\text { Training is systematic development of the } \\
\text { knowledge, skills and attitudes required by an } \\
\text { individual to perform adequately a given task } \\
\text { or job. }\end{array}$ \\
\hline 22 & 2005 & $\begin{array}{c}\text { Chiang, C. F., } \\
\text { Back, K., \& } \\
\text { Canter, D. }\end{array}$ & $\begin{array}{c}\text { The impact of employee training } \\
\text { on job satisfaction and intention to } \\
\text { stay in the hotel industry. Journal } \\
\text { of Human Resources in Hospitality } \\
\text { \& Tourism, 4(2), 99-118. }\end{array}$ & $\begin{array}{l}\text { Training quality had a positive relationship } \\
\text { with effecting job satisfaction and thus } \\
\text { increased an employee's intention to stay in } \\
\text { the hotel industry. }\end{array}$ \\
\hline 23 & 2008 & $\begin{array}{l}\text { Li J., Qian, G., } \\
\text { Liao, S. \& } \\
\text { Chu, C.W.L. }\end{array}$ & $\begin{array}{c}\text { Human resource management and } \\
\text { the globalness of firms: An } \\
\text { empirical study in China. The } \\
\text { International Journal of Human } \\
\text { Resource Management, } 19(5): \\
828-839 . \\
\end{array}$ & $\begin{array}{l}\text { Training refers to activities which equip } \\
\text { employees or upgrades workers with needed } \\
\text { skills to perform/ carry out better in their } \\
\text { present jobs. }\end{array}$ \\
\hline \multicolumn{5}{|c|}{ Compensation } \\
\hline 26 & 2010 & Pearce, L. & $\begin{array}{l}\text { Managerial compensation based } \\
\text { on organization performance, } \\
\text { Journal of industrial Relation, } \\
52: 3-28 \text {. }\end{array}$ & $\begin{array}{l}\text { Compensation implies having a compensation } \\
\text { structure in which the employees who } \\
\text { perform better are paid more than the average } \\
\text { performing employees. }\end{array}$ \\
\hline 27 & 2011 & Bob, N. & $\begin{array}{l}\text { Making employees suggestions } \\
\text { Count, Journal of personnel } \\
\text { management } 17 ; 20-41 .\end{array}$ & $\begin{array}{c}\text { Compensation processes are based on } \\
\text { compensation Philosophies and strategies and } \\
\text { contain arrangement in the shape of Policies } \\
\text { and strategies, guiding principles, structures } \\
\text { and procedures which are devised and } \\
\text { managed to provide and maintain appropriate } \\
\text { types and levels of pay, benefits and other } \\
\text { forms of compensation. }\end{array}$ \\
\hline
\end{tabular}

Since the emergence of HRM-performance debate, two broad research streams have emerged to examine the relationship between HRM and performance. The first one follows a direct approach between individual HR practices and/or a bundle of HR practices and performance (Chand \& Katou, 2007). The second research stream has focused on the indirect relationship between individual HR practices and/or a bundle of HR practices and organisational performance (Wright \& Gardner, 2003). Researchers studied the impact of HR practices on performance. It is based on the assumption that there is an appropriate level of analysis to 
examine the impact of organization-level performances (Delaney \& Huselid, 1996). It is presumed that a bundle of HR practices should generate better effects because the whole is considered greater than the sum of its parts. For example, to recruit and select best employees without training them, or train and develop them without giving them the authority to take decisions, will produce little or no effects; whereas implementing the three practices together would produce far better results. (Wall \& Wood, 2005). This is in contrast to individual HR practices that, in isolation can produce only a limited competitive advantage (Barney, 1995). Though there is no common understanding among researchers on what those practices should be, or on the number of practices that may enhance organizational performance (Dyer \& Reeves, 1995; Wright \& Gardner, 2003; Guest, 2011).

Many studies throughout the world have shown that positive correlation exists between HRM practices (taken jointly or severely) and organizational performance (Wagner, 1994; Milkvoich, 1994). The studies pertain both to manufacturing as well as service sectors (Huselid, 1995 ; Pfeffer, 1994,1998; MacDuffie, 1995; Rashid \& Anantharaman, 1999).

\section{Data Analysis and Interpretations}

Since each of the organization does possess certain unique characteristics, the results are bound to differ from each other .Table 1.1 and 1.2 depicts the overall perception of managers and subordinates towards the Human resource management practices in sample study organization. The public sector bank includes PNB and SBI. The results of public sector and private sector differ, but also the results of the organization within the same sector differs . It is clear from the table 5.1 , that the highest percentage of $32.5 \%$ of managers from PNB strongly agree that general climate of an organization is good that plays important role to improve the performance of an organization while SBI with $34.9 \%$ of agree and is statistically significant (p-value $\leq 0.0001$ ). PNB with a score of $51.9 \%$ of agree leads all the organizations with the perception the OCTAPACE culture has direct impact on the organizational performance SBI with $35.7 \%$ and is statistically significant with p-value $\leq 0.0001$. The result from the table shows that $62.1 \%$ of managers of PNB perceives that bank has good selection process and techniques that leads to effective performance of an organization and SBI with $24.1 \%$ and is statistically significant (p- value $\leq 0.0001$ ). The table shows that $63.6 \%$ of PNB managers agree with the statements of Job definitions followed by SBI with $37.0 \%$. It is clear from the result that if job description and job specifications will be clear to the employees that will directly improve performance of an employees and leads to the increase in the performance of an organization. The majority of the managers from all the sample study organizations either agree or strongly agree that career planning is clear to all the employees and is statistically significant. The table also depicts that the employee's participation is very important to improve organizational performance. Both managers of PNB and SBI agree with the performance appraisal variable of HRM practice with the highest percentage of $50.6 \%$ in PNB and SBI (40.5\%) which implies performance appraisal and organizational performance are closely linked with each other. Training plays an important role in enhancing the skills of an employees and 57.6\% of PNB managers agree with the training variable of HRM practice followed by the managers of SBI with $50.9 \%$.The results shows that $29.1 \%$ of PNB managers strongly agree that company takes care of 


\section{$\triangle$ Macrothink}

International Journal of Human Resource Studies ISSN 2162-3058 2018, Vol. 8, No. 1

employees while setting the compensation followed by $\operatorname{SBI}(16.7 \%)$ with p-value $\leq 0.0001$ and is statistically significant. After analyzing the above table 1.1, we can accept all alternate hypotheses that HRM practices are closely related with organizational performance and HRM has positive impact on organizational performance and reject null hypothesis.

It is also clear from table 1.2 that overall perception of subordinates varies from PNB and SBI. For general climate, OCTAPACE culture and selection the highest percentage of strongly agree is shown by the subordinates of PNB $(15.6 \%, 22.1 \%$ and $26.8 \%)$ and are statistically significant with $\mathrm{p}$-value $\leq 0.0001$. In job definition the highest percentage of strongly agree is shown by the subordinates of PNB (20.2\%), and SBI (12.3\%) . The respondents from both the banks agree in the following order PNB (38.1\%), and SBI $(33.3 \%)$ towards the career planning of HRM variable .It was observed that $34.6 \%$ of subordinates of SBI strongly disagree with the statement of employees participation while $30.3 \%$ of PNB agree that employees participation plays major role in enhancement of organizational performance. The table reveals that $54.5 \%$ of PNB subordinates agree with the statement of performance appraisal and SBI $(25.7 \%)$ and is statistically significant with p-value $\leq 0.0001$. The highest percentage of agree for training variable is shown by the subordinates by PNB (41.4\%) and SBI (35.8\%). The table depicts that 34.5\% of PNB subordinates agree with compensation variable of HRM practices followed by $32.5 \%$ of HDFC subordinates and $21.4 \%$ of JKB subordinates while $31.9 \%$ of SBI subordinates strongly disagree and is statistically significant with p-value $\leq 0.0001$. From the table 1.2 it is clear that perception of employees towards HRM practices is positive. This indicates that HRM practices are positively related with organizational performance and HRM practices has direct impact on organizational performance.

Table 1.1. Index of overall perception of managers towards Human resource management practices - organization-wise

\begin{tabular}{|c|c|c|c|c|c|c|c|c|}
\hline \multirow{2}{*}{ Variables } & \multirow{2}{*}{ Banks } & \multirow{2}{*}{$\begin{array}{l}\text { Sample } \\
\text { size (n) }\end{array}$} & \multicolumn{5}{|c|}{ Agreement (\%) } & \multirow[t]{2}{*}{ p-value } \\
\hline & & & $\begin{array}{l}\text { Strongly } \\
\text { disagree }\end{array}$ & Disagree & Neutral & Agree & $\begin{array}{c}\text { Strongly } \\
\text { agree }\end{array}$ & \\
\hline \multirow{2}{*}{$\begin{array}{l}\text { General } \\
\text { Climate(GC) }\end{array}$} & PNB & 11 & 1.3 & 5.2 & 22.1 & 39.0 & 32.5 & \multirow[t]{2}{*}{$\leq 0.0001^{*}$} \\
\hline & SBI & 18 & 17.5 & 7.1 & 12.7 & 34.9 & 27.8 & \\
\hline \multirow{2}{*}{$\begin{array}{l}\text { OCTAPACE } \\
\text { Culture(OC) }\end{array}$} & PNB & 11 & 0.2 & 7.8 & 11.7 & 51.9 & 28.6 & \multirow[t]{2}{*}{$\leq 0.0001^{*}$} \\
\hline & SBI & 18 & 17.5 & 15.1 & 7.1 & 35.7 & 24.6 & \\
\hline \multirow[t]{2}{*}{ Selection(S) } & PNB & 11 & 0.0 & 4.5 & 9.1 & 24.2 & 62.1 & \multirow[t]{2}{*}{$\leq 0.0001^{*}$} \\
\hline & SBI & 18 & 14.8 & 0.9 & 9.3 & 50.9 & 24.1 & \\
\hline \multirow{2}{*}{$\begin{array}{l}\text { Job } \\
\text { Definition(JD) }\end{array}$} & PNB & 11 & 0.0 & 0.0 & 0.0 & 63.6 & 36.4 & \multirow[t]{2}{*}{$\leq 0.0001^{*}$} \\
\hline & SBI & 18 & 1.9 & 7.4 & 13.0 & 37.0 & 40.7 & \\
\hline \multirow{2}{*}{$\begin{array}{l}\text { Career } \\
\text { planning }(\mathbf{C P})\end{array}$} & PNB & 11 & 1.3 & 3.9 & 15.6 & 51.9 & 27.3 & \multirow[t]{2}{*}{$\leq 0.0001^{*}$} \\
\hline & SBI & 18 & 5.6 & 13.5 & 17.5 & 40.5 & 23.0 & \\
\hline \multirow{2}{*}{$\begin{array}{l}\text { Employees } \\
\text { participation(EP) }\end{array}$} & PNB & 11 & 6.1 & 6.1 & 48.5 & 30.3 & 9.1 & \multirow[t]{2}{*}{$\leq 0.0001^{*}$} \\
\hline & SBI & 18 & 24.1 & 16.7 & 18.5 & 29.6 & 11.1 & \\
\hline \multirow{2}{*}{$\begin{array}{l}\text { Performance } \\
\text { Appraisal(PA) }\end{array}$} & PNB & 11 & 1.3 & 0.0 & 19.5 & 50.6 & 28.6 & \multirow[t]{2}{*}{$\leq 0.0001^{*}$} \\
\hline & SBI & 18 & 9.5 & 10.3 & 24.6 & 40.5 & 15.1 & \\
\hline \multirow[t]{2}{*}{ Training(T) } & PNB & 11 & 0.0 & 12.1 & 12.1 & 57.6 & 18.2 & \multirow[t]{2}{*}{$\leq 0.0001^{*}$} \\
\hline & SBI & 18 & 7.4 & 9.3 & 12.0 & 50.9 & 20.4 & \\
\hline \multirow{2}{*}{$\begin{array}{l}\text { Compensation } \\
\text { (C) }\end{array}$} & PNB & 11 & 3.6 & 23.6 & 40.0 & 29.1 & 29.1 & \multirow[t]{2}{*}{$\leq 0.0001^{*}$} \\
\hline & SBI & 18 & 26.7 & 26.7 & 21.1 & 16.7 & 16.7 & \\
\hline
\end{tabular}


Table 1.2. Index of overall perception of subordinates towards Human resource management practices - organization-wise

\begin{tabular}{|c|c|c|c|c|c|c|c|c|}
\hline \multirow{2}{*}{ Variables } & \multirow{2}{*}{ Banks } & \multirow{2}{*}{$\begin{array}{l}\text { Sample } \\
\text { size (n) }\end{array}$} & \multicolumn{5}{|c|}{ Agreement (\%) } & \multirow{2}{*}{ p-value } \\
\hline & & & $\begin{array}{l}\text { Strongly } \\
\text { disagree }\end{array}$ & Disagree & Neutral & Agree & $\begin{array}{c}\text { Strongly } \\
\text { agree }\end{array}$ & \\
\hline \multirow{2}{*}{$\begin{array}{l}\text { General } \\
\text { Climate(GC) }\end{array}$} & PNB & 33 & 8.2 & 16.9 & 21.2 & 38.1 & 15.6 & \multirow[t]{2}{*}{$\leq 0.0001^{*}$} \\
\hline & SBI & 54 & 18.5 & 26.5 & 28.0 & 20.4 & 6.6 & \\
\hline \multirow{2}{*}{$\begin{array}{l}\text { OCTAPACE } \\
\text { Culture(OC) }\end{array}$} & PNB & 33 & 0.4 & 16.5 & 22.9 & 38.1 & 22.1 & \multirow[t]{2}{*}{$\leq 0.0001^{*}$} \\
\hline & SBI & 54 & 12.2 & 18.8 & 22.0 & 32.0 & 15.1 & \\
\hline \multirow[t]{2}{*}{ Selection(S) } & PNB & 33 & 0.0 & 12.6 & 17.2 & 43.4 & 26.8 & \multirow[t]{2}{*}{$\leq 0.0001 *$} \\
\hline & SBI & 54 & 7.1 & 16.7 & 26.5 & 36.1 & 13.6 & \\
\hline \multirow{2}{*}{$\begin{array}{l}\text { Job } \\
\text { Definition(JD) }\end{array}$} & PNB & 33 & 0.0 & 13.1 & 22.2 & 44.4 & 20.2 & \multirow[t]{2}{*}{$\leq 0.0001^{*}$} \\
\hline & SBI & 54 & 7.4 & 10.5 & 25.3 & 44.4 & 12.3 & \\
\hline \multirow{2}{*}{$\begin{array}{l}\text { Career } \\
\text { planning }(\mathrm{CP})\end{array}$} & PNB & 33 & 3.5 & 14.3 & 22.9 & 38.1 & 20.3 & \multirow[t]{2}{*}{$\leq 0.0001^{*}$} \\
\hline & SBI & 54 & 10.1 & 22.5 & 21.2 & 33.3 & 13.0 & \\
\hline \multirow{2}{*}{$\begin{array}{l}\text { Employees } \\
\text { participation(EP) }\end{array}$} & PNB & 33 & 4.0 & 31.3 & 26.3 & 30.3 & 8.1 & \multirow[t]{2}{*}{$\leq 0.0001^{*}$} \\
\hline & SBI & 54 & 34.6 & 28.4 & 13.0 & 17.9 & 6.2 & \\
\hline \multirow{2}{*}{$\begin{array}{l}\text { Performance } \\
\text { Appraisal(PA) }\end{array}$} & PNB & 33 & 0.4 & 12.6 & 26.0 & 54.5 & 6.5 & \multirow[t]{2}{*}{$\leq 0.0001^{*}$} \\
\hline & SBI & 54 & 11.4 & 29.4 & 27.8 & 25.7 & 5.8 & \\
\hline \multirow[t]{2}{*}{ Training(T) } & PNB & 33 & 2.0 & 25.3 & 15.7 & 41.4 & 15.7 & \multirow[t]{2}{*}{$\leq 0.0001^{*}$} \\
\hline & SBI & 54 & 13.9 & 24.1 & 20.4 & 35.8 & 5.9 & \\
\hline \multirow{2}{*}{$\begin{array}{l}\text { Compensation } \\
\text { (C) }\end{array}$} & PNB & 33 & 3.0 & 27.9 & 24.2 & 34.5 & 10.3 & \multirow[t]{2}{*}{$\leq 0.0001 *$} \\
\hline & SBI & 54 & 31.9 & 27.0 & 16.7 & 18.9 & 5.6 & \\
\hline
\end{tabular}

8.1 Perceptions of Managers and Subordinates towards the Overall HRM Practices in Public Sector

Comparing the organizations within the public sector, it is amply clear from the results presented in the table no. 1.3 that mean values of all HRM practice variables among managers in case of PNB are higher than the mean values of HRM practice variables of the SBI. The table under reference depicts that the overall satisfaction/ perception of managerial staff fall in the satisfactory range of scale. The overall mean values, of managerial group are $>70 \%$ except for employee participation and compensation. The table also depicts that the overall mean values of subordinates fall in satisfactory range of scale and recorded overall percentage of mean score $>60$ in PNB except for the employees participation and compensation.. The overall mean score of managers against General climate is 3.96(74.00) which are marginally higher than subordinates which is recorded at 3.36(59.00). The table also shows that managerial staff recorded highest mean and scored $>85 \%$ against selection with the mean score 4.44. On the other hand subordinates of PNB shows the highest mean score of 3.92(73.00) against career planning. The table also reflects the lowest mean score 3.05(51.25) of managerial staff recorded against the compensation variable. The rest of the variables scored by manager's shows reasonably good response. When we look at the table 5.30, the interesting observation comes into light that subordinates express positive view against selection and career planning which scored $>70 \%$. However the rest of HRM variables scored by subordinates show good response. But overall satisfaction of managers is higher than the subordinates Which is indication of the fact that there is a tremendous scope of improvement of various HRM practices in case of subordinates is concerned.

The perception of managerial group of SBI also falls in satisfactory range of scale as 
compared to subordinates. The table amply that the overall mean values of managers

Recorded $>60 \%$ for HRM variables except for employees participation and compensation. The table also shows that managerial staff recorded highest mean and scored $>70 \%$ against job definition with the mean score 4.07. On the other hand subordinates of SBI shows the highest mean score of 3.44(61.00) against job definition. The table also reflects the lowest mean score 2.54(38.50) of managerial staff recorded against the compensation variable. The rest of the variables scored by manager's shows reasonably good response. When we look at the table 5.31, the interesting observation comes into light that subordinates express positive view against job definition $>60 \%$. The lowest mean score(2.33) is recorded in employee participation among subordinates of SBI. However the rest of HRM variables scored by subordinates show average response. Which is indication of the fact that there is a tremendous scope of improvement of various HRM practices in case of subordinates is concerned.

It is clear from the table that overall mean score or its percentage linked across all the HRM practice variable of the employees both managers and subordinates in SBI are less satisfied as compared to the employees of PNB. Thus it is clear from the table 5.30 that contradictory statements among the managers and subordinates in both the organization are observed. Managers claim that top management goes out of their way to make sure that employee enjoy their work. Managerial personnel also claim that they always help their subordinates and presume development of subordinate is very important job in both the organization. On the other hand interesting observation come to light that subordinates blame that employees participation is rare in making any decision and compensation is not based on competency or ability of an employee. However as compared to managers, subordinates are highly dissatisfied with existing HRM practices in both the organizations. The situation in case of PNB is comparatively better than SBI which is clearly reflected from overall mean values and their respective percentage ranging between 3.05(51.25) to 4.44(86.00) in managers and $3.07(51.75)$ to $3.92(73.00)$ in case of subordinates of PNB. While in SBI overall mean values and their respective percentage ranging between 2.54(38.50) to 4.07(76.75) in managers and 2.33(33.25) to 3.44(61.00) in case of subordinates. As a whole while looking the above analysis, we conclude that overall managers are more satisfied than subordinates towards the HRM practices in the sample study organization. We can also conclude that satisfaction level of PNB employees towards the HRM practices is higher than SBI employees. Higher the level of satisfaction higher is the organizational performance thus our alternate hypothesis is accepted the HRM practices are closely related with organizational performance and null hypothesis is rejected. 
Table 1.3. Perceptions of managers and subordinates towards the overall HRM practices in public sector

\begin{tabular}{c|c|c|c|c|c|c|c|c}
\hline \multirow{2}{*}{ Variables } & \multicolumn{2}{c|}{$\begin{array}{c}\text { PNB } \\
\text { Managers }\end{array}$} & \multicolumn{2}{c|}{$\begin{array}{c}\text { PNB } \\
\text { Subordinates }\end{array}$} & \multicolumn{2}{c|}{$\begin{array}{c}\text { SBI } \\
\text { Managers }\end{array}$} & \multicolumn{2}{c}{ SBI subordinate } \\
\cline { 2 - 10 } & $\begin{array}{c}\text { Mean } \\
\text { score }\end{array}$ & $\begin{array}{c}\text { Mean } \\
\text { score }\end{array}$ & $\begin{array}{c}\text { Mean } \\
\text { score }\end{array}$ & $\begin{array}{c}\text { Mean } \\
\text { score }\end{array}$ & $\begin{array}{c}\text { Mean } \\
\text { score }\end{array}$ & $\begin{array}{c}\% \\
\text { Mean } \\
\text { score }\end{array}$ & $\begin{array}{c}\text { Mean } \\
\text { score }\end{array}$ & $\begin{array}{c}\text { Mean } \\
\text { score }\end{array}$ \\
\hline General Climate & 3.96 & 74.00 & 3.36 & 59.00 & 3.48 & 62.00 & 2.70 & 42.50 \\
\hline $\begin{array}{c}\text { OCTAPACE } \\
\text { culture }\end{array}$ & 4.01 & 75.25 & 3.65 & 66.25 & 3.35 & 58.75 & 3.19 & 54.75 \\
\hline Selection & 4.44 & 86.00 & 3.84 & 71.00 & 3.69 & 67.25 & 3.32 & 58.00 \\
\hline Job Definition & 4.36 & 84.00 & 3.72 & 68.00 & 4.07 & 76.75 & 3.44 & 61.00 \\
\hline Career Planning & 4.00 & 75.00 & 3.92 & 73.00 & 3.62 & 65.50 & 3.17 & 54.25 \\
\hline $\begin{array}{c}\text { Employee } \\
\text { Participation }\end{array}$ & 3.30 & 57.50 & 3.07 & 51.75 & 2.87 & 46.75 & 2.33 & 33.25 \\
\hline $\begin{array}{c}\text { Performance } \\
\text { Appraisal }\end{array}$ & 4.05 & 76.25 & 3.54 & 63.50 & 3.41 & 60.25 & 2.85 & 46.25 \\
\hline Training & 3.82 & 70.5 & 3.43 & 60.75 & 3.48 & 67.00 & 2.96 & 49.00 \\
\hline compensation & 3.05 & 51.25 & 3.21 & 55.25 & 2.97 & 48.75 & 2.39 & 34.75 \\
\hline
\end{tabular}

\section{Conclusion and Suggestions}

Most of the researchers and the human resource practitioners agree that performance of employees is the key to success for any organization. The better the employees perform, the more the successful the organization is. If the organizations do not focus on its human resource management, not only the goals remain unaccomplished but work performance also suffers. Therefore, organizations must take its human resource management responsibility seriously for the enhancement of their employee's performance and accomplishment of their goals. The study of HRM practices and its impact on organizational performance in the sample study organization suggest they face number of challenges to ensure the professional and organizational commitment of officials in order to provide quality services to the people. Effective human resource management issues raised in this research would lead to better implementation of reform processes. An attempt was made to understand the relationship of different HRM practices with perceptional organizational performance in banking industry in India with a view to a) to understand the relationship between HRM practices and organizational performance b) to identify the whether there is a positive or negative impact of HRM practices on organizational performance c) to critically review the HRM practices in the sample study organization and d) to provide some relevant measures that can enhance the organizational performance of the sample organizations under study . The results also indicate that the employees of PNB are more satisfied than the employees of SBI

In order to achieve and meet with the worldwide standards and to sustain in a competitive market banks need to create such an organizational climate and implement HRM practices that has great impact on the quality of organizational performance.

\section{Limitation and Direction for Future Research}

The study was confined to investigate the impact of HRM practices on organizational performance in banks and compare HRM practices in PNB and SBI. The research study made 
number of limitations. The main limitation of this research study is about sampling issue as the small sample size was small that may have affected the research results. Even our research findings might have depicted certain results these findings cannot be construed as an independent model to ensure performance of the organizations. Nonetheless, this model has provided insight into possible reasons for organizational performance. In addition to that, the study focused on perceptions of organizational performance and HRM practices as reported by the employees. Hence it is subject to common source and common method bias as perception varies from person to person. The study did not cover all the HRM practice variables that have an impact and relationship with organizational performance.

Several suggestions and recommendation that are fruitful for future research emerged from this present study. In order to validate the findings of the study, case study, focus groups and longitudinal studies are another interesting approach that can be undertaken for future research. Additionally, the research model of this study can be tested in other service sector like education, airlines, hotels, hospitals and tourism with the large sample size so that the research model can be generalized.

\section{References}

Agarwal, E. T. (2002). The Practice of HRD: Internal Customers view The Journal of Business Perspective, 25-32.

Agarwala, T. (2002). Innovative Human Resource Practices and HRD Climate: A Comparison of Automobile and IT Industries, in Pareek, Osman-Gani, Ramnarayan \& Rao T.V (Eds.), Human Resource Development in Asia, New Delhi: Oxford \& IBH: 3-10.

Andrews, S. (2009). Human resource management: A textbook for the hospitality industry. New Delhi: McGraw-Hill Publishing Company Ltd.

Armstrong, M. (2001). A Handbook of Human Resource Management Practice, Kogan Page, $8^{\text {th }}$ Ed.

Bandarker, A. (2003). Building corporate transformation ${ }^{\circ} \mathrm{New}$ HR agends, The Journal of Business Perspective, 1-23

Barney, J. (1995). Looking inside for Competitive Advantage. Academy of Management Review, 9(4), 49-61. https://doi.org/10.5465/AME.1995.9512032192

Becker, B., \& Gerhart, B. (1996). The impact of HRM on or gl. Performance: Progress and prospectus, Academy of Mgt. Journal, 39(4), 836-866. https://doi.org/10.2307/256712

Billmes, L., Wetzeker, K., \& Xhonneux, P. (1997). Value in Human Resources, Financial Times.

Bob, N. (2011). Making employees suggestions Count, Journal of Personnel Management, $17,20-41$.

Boudriau, J. W. (1991). Utility Analysis in FIRM Decisions, In M.D. Dunnette \& M. Hough (EDs.), Handbook of Industrial and Organisational Psychology (2nd ed.), 2, 621-745, 
Consulting Psychologists Press, Palo Alto, CA.

Bowen, D. E., Galang, C., \& Pillai, R. (2002). The role of FIRM: An exploratory study of cross-country variance, HRM, 41(I), 103-122.

Chand, M., \& Katou, A. (2007). The Impact of HRM practices on organizational performance in the Indian hotel Industry, Employee Relations, 29(6), 576-594. https://doi.org/10.1108/01425450710826096

Chiang, C. F., Back, K., \& Canter, D. (2005). The impact of employee training on job satisfaction and intention to stay in the hotel industry. Journal of Human Resources in Hospitality \& Tourism, 4(2), 99-118. https://doi.org/10.1300/J171v04n02_06

Delaney, J. T., \& Huselid, M. A. (1996). The Impact of Human Resource Management Practices on Perceptions of Organizational Performance: The Academy of Management Journal, 39(4), 949-969. https://doi.org/10.2307/256718

Delery, J. E., \& Doty, D. H. (1996). Modes of theorizing in strategic human resource management: tests of universalistic, contingency and configurational performance predictions, Academy of Management Journal, 39(4), 802-835. https://doi.org/10.2307/256713

Dyer, L., \& Reeves, T. (1995). Human resource strategies and firm performance: What do we know and where do we need to go? International Journal of Human Resource Management, 6, 656-670. https://doi.org/10.1080/09585199500000041

Foss, N. J., Laursen, K., \& Pedersen, T. (2011). Linking Customer Interaction and Innovation: The Mediating Role of New Organizational Practices. Organization Science, 22(4), 980-999. https://doi.org/10.1287/orsc.1100.0584

Guest, D. (1997). Human resource management and performance: A review and research agenda, International Journal of Human Resource Management, 8(3), 263-276. https://doi.org/10.1080/095851997341630

Guest, D. E. (2011). Human resource and management and performance: Still searching for some answers, Human Resource Management Journal, 22(1), 3-13. https://doi.org/10.1111/j.1748-8583.2010.00164.x

Heller, F., Pusic, E., Strauss, G., \& Wilpert, B. (1998). Organisational Participation: Myth and Reality, Oxford: Oxford University Press.

Huselid, M. A. (1995). The Impact of Human Resource Practices on Turnover, Productivity, and Corporate Financial Performance, Academy of Management Journal, 38, 635-672. https://doi.org/10.2307/256741

Huselid, M. A., \& Becker, B. (1995). High performance work systems and gattraional performance, paper presented at the annual meeting of academy of Management, Vancouver.

Huselid, M. A., \& Becker, B. E. (1997). The impact of High Performance Work Practice, Implementation effectiveness and alignment with Strategy on share- holder wealth, unpublished Paper, Rutgers University, New Brunswick, N.J., 18-19. 
Hussain, A. M., \& Opatha, H. H. D. N. P. (2008). Performance appraisal and business performance: An empirical study in Sri Lankan apparel industry. SriLankan J. Hum. Resour. Manage., 2(1), 74-90.

Jawahar, I. M. (2006). Correlates of satisfaction with performance appraisal feedback. Journal of Labor Research, 27(2), 213-236. https://doi.org/10.1007/s12122-006-1004-1

Johnes, G. R., \& Wright, P. M. (1992). An Economic Approach to Conceptualizing The utility of HRM practices, In K. Rowland \& G. Ferris (EDs.), Research in Personnel and HRM, 10, 271-299.

Kleiner, M. M. (1990). The Role of industrial Relations in firm performance, in J.A sum \& J Mattson (eds), Employee and labour Relations, B.N.A Washington D.c.

Levine, D., \& Tyson, L. (1990). Participation, productivity and the firm's Environment. In A. Blindered .Paying for Productivity: A Look at the Evidence, Washington D.C: Brooklings Institute. https://doi.org/10.2307/41166630

Li, J., Qian, G., Liao, S., \& Chu, C. W. L. (2008). Human resource management and the globalness of firms: An empirical study in China. The International Journal of Human Resource Management, 19(5), 828-839. https://doi.org/10.1080/09585190801991293

Locke, E. A., \& Schweiger, D. M. (1997). Participation in Decision-making: One More Look. Research in Organizational Behaviour, 1, 265-339.

MacDuffie, J. P. (1995). Human resource bundles and manufacturing performance: organizational logic and flexible production systems in the world auto industry, Industrial and Labor Relations, 48, 197-221. https://doi.org/10.1177/001979399504800201

Manolescu, A. (2003). Human Resource Management, 4th Edition, The Economic Publishing House, Bucarest, p.332

Megginson, L. C. (1972). Personnel Richard. D. Irwin. Inc. Homewood, Illnois, p. 14.

Mejia L. R., Gpmoz, B., David, B., \& Cardy, R. (2003). Arizona State University, Managing Human Resources Print ice Hall of India, New Delhi 110001.

Michael, V. P. (1993). Perspective Management, Himalaya Publishing House Bombay, 682.

Mitsuhashi, H., Park, H., Jeong, W., Patrick, M., \& Chua, R. S. (2000). Line and HR Executives' Perceptions of HR effectiveness in firms in the peoples Republic of China. International Journal of HRM, 11(2), 197-216.

Newstrom, \& Davis. (2004). In Bhuiyan, M. H. (2010). Employee Participation in Decision Making in RMG sector of Bangladesh: Correlation with Motivation and Performance. Journal of Business and Technology (Dhaka), 5(2), 122-132.

Pal, S. S. (1997). Organizational thrusts Re-orientation in public sector (44-1ter.pr-i-sq for Human Resource Development in the new economic environment, TD, xxvii(3).

Pavur, E. R. (2010). Use job descriptions to support leadership. The Psychologist-Manager 
Journal, 13(2), 119-122. https://doi.org/10.1080/10887151003776596

Pearce, L. (2010). Managerial compensation based on organization performance, Journal of Industrial Relation, 52, 3-28.

Pfeffer, J. (1994). Competitive advantage through people: Unleasing the power of the workforce. Boston: Harvard Business School Press.

Pfeffer, J. (1998). Seven practices of successful organizations, California Management Review, 40, 96-124. https://doi.org/10.2307/41165935

Pynes, J. E. (2009). Human resources management for public and nonprofit organizations: A strategic approach. USA: A Wiley Imprint.

Qureshi, M. T., \& Ramay, I. M. (2006). Impact of Human Resource Management Practices on Organizational Performance in Pakistan, Muhammad Ali Jinnah University, Islamabad.

Rao, T. V. (1992). Appraising and developing managerial performance. Academy of HRD, Ahmedabad, India.

Rao, T. V. (1999). HRD Audit, New Delhi: Response Books (A Division of Sage Publications) New Delhi.

Rashid, A. Z., \& Anantharaman, R. N. (1999). Human Resource Management Practices: Perceived Organizational Market Performance, Management and Chan.

Scarpello, V. (1994). A longitudinal assessment of the determinant relationship between employee commitments to the occupation and the organization. Journal of Organizational Behavior, 15(6), 535-547. https://doi.org/10.1002/job.4030150605

Schuler, R., Dowling, P., \& Decieri, H. (1993). An Integrative Framework of strategic Int. $\begin{array}{llll}\text { HRM. Journal of } & \text { Management, } & \text { 19(2), }\end{array}$ https://doi.org/10.1177/014920639301900209

Schuler. (1994). World class HR Department. Accounting and Business review, 1. https://doi.org/10.1142/S0218556394000048

Shadur, M. A., \& Teo, S. T. T. (1999). How Strategic is FIRM? Evidence of strategic integration in Australian organizations, IJIR, 35(I).

Sharif, N. A. S., Peter, J. D., \& Peter, W. L. (1998). The role of H-Rishfir International joint ventures: A study of Australian - Indian joint ventures, International Journal of HRM, 9(5), 751-766.

Singh, K. (2000). Effect of human resource management practices on firm performance in India, Indian Journal of Industrial Relations, 36(1), 1-23.

Sudin, S. (2011). Fairness of and satisfaction with performance appraisal process. $2^{\text {nd }}$ International Conference on Business and Economic Research.

Tung, C. H. (2002). Are human resource practices of effective firms distinctly different from 


\section{Macrothink}

International Journal of Human Resource Studies

ISSN 2162-3058 2018, Vol. 8, No. 1

those of poorly performing ones? Evidence from Taiwanese enterprises. International Journal of HRM, 11(2), 436-451.

Ulrich, D. (1998). A new mandate of human resources, Harvard Business Review, 41, 124-134.

Vandana, \& Punia, B. K. (2004). Intritine Abilities and HR Effectiveness A Study of Educational Manager, University news, 42(5), 2-8.

Wagner, J. A. (1994). Participations effects on performances and satisfaction: A reconsideration of research evidence, Academy of Management Review, 19(3), 12-33.

Wall, T. D., \& Wood, S. (2005). The romance of human resource management and business performance, and the case for big science, Human Relations, 58, 429-62. https://doi.org/10.1177/0018726705055032

Wright, P. M., Mcmahan, G. C., Snell, S. A., \& Gerhart, B. (2001). Comparing Line and HR executives perceptions of HR effectives: Services, Roles and Contributions HRM Summer, $40(2)$.

Wright, P., \& Gardner, T. M. (2003). The human resource-firm performance relationship: Methodological and theoretical challenges', In The new workplace: A guide to the human impact of modern working practices, eds D. Holman, T. D. Wall, C. W. Clegg, P. Sparrow, \& Howard, A. pp. 311-28. West Sussex, UK: Wiley.

\section{Copyright Disclaimer}

Copyright for this article is retained by the author(s), with first publication rights granted to the journal.

This is an open-access article distributed under the terms and conditions of the Creative Commons Attribution license (http://creativecommons.org/licenses/by/4.0/). 